\title{
Pengaruh Pendekatan Saintifik Terhadap Hasil Belajar Pokok Bahasan Persegi, Persegi Panjang dan Segitiga Pada Siswa Kelas III SDN Kebonsari 04 Jember \\ (The Effect of Scientific Approach Toward Third Grade Student Learning Outcomes on The Square, Rectangle, and Triangle Material at SDN Kebonsari 04 Jember)
}

\author{
Irawan Tri Hartanto, Titik Sugiarti, Agustiningsih \\ Prodi PGSD, Jurusan Ilmu Pendidikan, FKIP, Universitas jember (UNEJ) \\ Jln. Kalimantan 37, Jember 68121 \\ E-mail : titiksugiarti.fkip@unej.ac.id
}

\begin{abstract}
Abstrak
Pembelajaran matematika merupakan suatu proses pembelajaran aktif dan inovatif yang dilakukan oleh guru untuk meningkatkan kemampuan siswa dalam membangun pengetahuan baru sebagai upaya untuk meningkatkan hasil belajar. Salah satu pembelajaran yang aktif dan inovatif dalam pembelajaran matematika adalah pendekatan saintifik. Pendekatan saintifik merupakan pendekatan dalam pembelajaran yang terdapat lima komponen dalam pelaksanaannya yaitu mengamati, menanya, menalar, mencoba, dan mengkomunikasikan. Tujuan dari penelitian ini adalah untuk mengetahui adanya pengaruh yang signifikan pendekatan saintifik terhadap hasil belajar pokok bahasan persegi, persegi panjang, dan segitiga pada siswa kelas III SDN Kebonsari 04 Jember tahun ajaran 2017/2018. Jenis penelitian ini adalah penelitian eksperimen dengan pola pretest postest control group design. Pengumpulan data dalam penelitian ini menggunakan tes. Jenis tes yang digunakan adalah tes obyektif. Responden dalam penelitian ini yaitu siswa kelas III yang terdiri dari siswa kelas III A dan kelas III B SDN Kebonsari 04 Jember. Skor tes hasil belajar siswa berupa nilai pretest dan postest yang dianalisis dengan uji $\mathrm{t}$ menggunakan aplikasi SPSS versi 21. Hasil analisis dengan ujit diperoleh nilai $t_{\text {hitung }}=7,718$ dengan keefektifan relatif sebesar 71,88\%. Hasil perhitungan uji t dikonsultasikan pada taraf signifikansi 5\% sebesar 2,042 dan diketahui bahwa hasil $\mathrm{t}_{\text {hitung }}>\mathrm{t}_{\text {tabel }}$ atau 7,718>2,042. Dari hasil perhitungan tersebut, dapat disimpulkan bahwa ada pengaruh yang signifikan pendekatan saintifik terhadap hasil belajar pokok bahasan persegi, persegi panjang, dan segitiga pada siswa kelas III SDN Kebonsari 04 Jember tahun ajaran 2017/2018.
\end{abstract}

Kata Kunci: pembelajaran matematika, pendekatan saintifik, hasil belajar.

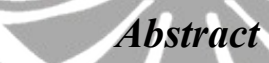

Mathematics learning is an active process of learning and innovative conducted by teachers to enhance students ability in developing new knowledge as an attempt to improve the results of study. One of active and innovative in mathematics learning is a scientific approach. Scientific approach is an approach in the learning that there are five components in its implementation that is to observe, ask, reason, try, and communicate. The purpose of this research is to know the existence significant effect of scientific approach towards learning outcomes subject of square, rectangular, and triangular in the grade III SDN Kebonsari 04 Jember 2017/2018 school year. This type of research is a experiment research with pattern pretest postest control group design. The collect of data in this research using the test. The type of test used is the objective test. Respondents in this research is grade III consisting of grade III A and III B class SDN Kebonsari 04 Jember. Test score results of student learning in the form of the value of pretest and postest analyzed by t-test using SPSS version 21. The results of the analysis with $t$-test is $t_{\text {count }}$ is 7.718 with the relative effectiveness is $71.88 \%$. The results of the calculation of the t-test consulted on $5 \%$ of significance level 2.042 and noted that the results of the $t_{\text {count }}>t_{\text {table }}$ or $7.718>2.042$. From the results of the calculation, it can be concluded that there is a significant effect of the scientific approach towards learning outcomes subject of square, rectangular, and triangular in the grade III SDN Kebonsari 04 Jember 2017/2018 school year.

Keywords : mathematics learning, scientific approach, result of study.

\section{Pendahuluan}

Menurut Sunardi dkk. (2017: 31) matematika merupakan salah satu mata pelajaran yang diajarkan pada siswa tingkat sekolah dasar hingga sekolah menengah. Matematika sering disebut sebagai ilmu pasti yang berkaitan dengan penalaran. Matematika memiliki obyek kajian ilmu abstrak yang 
menuntut siswa dapat berfikir secara rasional serta dapat dikaitkan dalam kehidupan sehari-hari.

Menurut Susanto (2013: 186) pembelajaran matematika adalah suatu proses belajar mengajar yang dibangun oleh guru untuk mengembangkan kreativitas berpikir siswa, serta dapat meningkatkan kemampuan mengkonstruksi pengetahuan baru sebagai upaya meningkatkan penguasa yang baik terhadap materi matematika. Menurut Sugiarti dkk. (2016: 11) kemampuan berpikir matematika menjadi salah satu tolak ukur tercapainya tujuan matematika, seperti kemampuan berpikir logis, kritis, kreatif, dan reflektif. Pembelajaran matematika dapat berjalan secara efektif apabila terjadi interaksi antara siswa dengan siswa, antara guru dengan siswa dan antara siswa dengan lingkungan sehingga dapat menciptakan pembelajaran aktif dan inovatif sesuai dengan tujuan pembelajaran matematika.

Salah satu pembelajaran yang aktif dan inovatif dalam pembelajaran matematika yang sesuai dengan tujuan pembelajaran matematika adalah pendekatan saintifik (Scientific Approach). Pendekatan ilmiah (Scientific Approach) adalah pendekatan dalam pembelajaran dengan menggunakan lima komponen yaitu komponen mengamati, menanya, menalar, mencoba, dan mengkomunikasikan (Kemendikbud, 2013).

Menurut Daryanto (dalam Musfiqon dan Nurdiansyah, 2015: 37) mengatakan bahwa pendekatan saintifik merupakan pendekatan dalam pembelajaran yang menggunakan langkah-langkah yang mengandung kaidah ilmiah dalam sebuah proses pembelajarannya. Kaidah ilmiah yang digunakan atau diterapkan dalam proses pembelajaran meliputi menemukan masalah, merumuskan masalah, mengajukan hipotesis, mengumpulkan data, menganalisis data, dan menarik kesimpulan. Tujuan pendekatan saintifik adalah untuk meningkatkan kemampuan berpikir tingkat tinggi siswa dalam menyelesaikan masalah matematika dan untuk memperoleh hasil belajar maksimal.

Pembelajaran matematika dengan materi mengidentifikasi bangun datar sederhana berdasarkan sifat dan unsurnya menggunakan pendekatan saintifik yang berpusat pada siswa, diawali dengan mengamati bangun datar, menanya sifat-sifat dan unsur bangun datar sederhana, menalar sifat dan unsur bangun datar, mencoba menemukan dan menggambar bangun datar, dan mengkomunikasikan sifat dan unsur bangun datar yang telah di identifikasi oleh siswa. Setelah dilakukan pembelajaran menggunakan pendekatan saintifik diharapkan dapat memunculkan rasa ingin tahu siswa yang tinggi. Selain itu, siswa diharapkan mendapat pengalaman belajar yang sangat bermakna dengan tujuan untuk mengembangkan kemampuan berpikir tingkat tinggi secara ilmiah, sehingga hasil belajar siswa menjadi maksimal.

Berdasarkan studi dokumen hasil ujian akhir semester (UAS) yang dilakukan di kelas III A dan kelas III B SDN Kebonsari 04 Jember dapat disimpulkan bahwa hasil belajar matematika kelas III masih rendah. Hal ini dapat dilihat dari hasil nilai ulangan akhir semester (UAS) siswa. Berdasarkan data ulangan akhir semester ganjil, masih banyak siswa kelas III yang mendapat nilai di bawah rata-rata. Pada kelas III A sebanyak $74 \%$ siswa memperoleh hasil belajar di bawah ratarata, sedangkan pada kelas III B sebanyak 93\% siswa memperoleh hasil belajar di bawah rata-rata. Oleh karena masih banyak terdapat hasil belajar siswa yang di bawah ratarata, maka diperlukan suatu cara untuk diterapkan pada pembelajaran matematika dengan menggunakan pendekatan saintifik.

Berdasarkan penjelasan yang telah dijabarkan, untuk meminimalisir masalah tersebut maka dilakukan penelitian dengan judul Pengaruh Pendekatan Saintifik Terhadap Hasil Belajar Pokok Bahasan Bangun Persegi, Persegi Panjang dan Segitiga.

\section{Metode Penelitian}

Jenis penelitian ini adalah penelitian eksperimen. Menurut Masyhud (2016: 138) penelitian eksperimen merupakan penelitian yang dirancang untuk mengetahui ada atau tidak ada pengaruh dari suatu perlakuan (treatment) tertentu terhadap perubahan suatu kondisi atau keadaan tertentu. Desain yang digunakan dalam penelitian ini menggunakan pola Pretest-Postest Control Group Design. Pola dalam desain ini adalah membentuk dua kelompok subyek penelitian, kelompok eksperimen dan kelompok kontrol. Masing-masing kelompok diberikan tes awal (pretest) untuk mengetahui kemampuan awal yang dimiliki sebelum dilakukan perlakuan (treatment). Setelah mengetahui kemampuan awal masing-masing kelompok, maka dilakukan perlakuan yang berbeda pada kelompok eksperimen dan kelompok kontrol tersebut. Setelah kedua kelompok diberikan perlakuan (treatment), maka diberikan postest untuk mengukur hasil akhir masing-masing kelompok.

Penelitian ini dilaksanakan di SDN Kebonsari 04 Jember pada semester genap tahun pelajaran 2017/2018. Adapun responden penelitian adalah siswa kelas III A dan III B dengan jumlah siswa pada masing-masing kelas sebanyak 31 siswa. Metode pengumpulan data dalam penelitian ini menggunakan tes. Tes digunakan untuk mengukur kemampuan siswa pada kelas eksperimen dan kelas kontrol. Data yang dianalisis dalam penelitian ini adalah sebagai berikut.

a. Validasi Tes Hasil Belajar

$V a=\frac{\sum_{i=1}^{n} l i}{n}$

Keterangan:
$\mathrm{Va}=$ nilai rata-rata total untuk semua aspek
$l i=$ rerata nilai untuk aspek ke-1-i
$\mathrm{n}=$ banyaknya aspek

Hasil $V a$ yang telah diperoleh kemudian dikonsultasikan pada tabel kriteria validitas instrumen yang sesuai pada tabel tersebut. Adapun tabel kriteria validitas instrumen digambarkan sebagai berikut (dimodifikasi dari Hobri, 2010: 52-53).

Tabel 1. Kriteria validitas instrumen

\begin{tabular}{|c|c|}
\hline Nilai $\boldsymbol{V a}$ & Tingkatan Kevalidan \\
\hline$V a=3$ & Sangat Valid \\
\hline $2,5<V a<3$ & Valid \\
\hline $2 \leq \mathrm{Va} \leq 2,5$ & Cukup Valid \\
\hline $1,5 \leq \mathrm{Va} \leq 2$ & Kurang Valid \\
\hline
\end{tabular}




\begin{tabular}{|c|c|}
\hline Nilai $\boldsymbol{V a}$ & Tingkatan Kevalidan \\
\hline $1 \leq \mathrm{Va} \leq 1,5$ & Tidak Valid \\
\hline
\end{tabular}

\section{b. Uji t (t-test) dan Tingkat Keefektifan Relatif(ER)}

Analisis data menggunakan uji t (t-test) dilakukan untuk mengetahui adanya pengaruh pendekatan saintifik terhadap hasil belajar. Menurut Masyhud (2016: 382) rumus uji t sampel terpisah adalah sebagai berikut.

$$
t=\frac{M_{2}-M_{1}}{\sqrt{\frac{\sum x_{1}^{2}+\Sigma x_{2}^{2}}{N(N-1)}}}
$$

Keterangan:

$M_{1}=$ Nilai rata-rata kelompok $\mathrm{x}_{1}$ (kelompok eksperimen)

$M_{2}=$ Nilai rata-rata kelompok $\mathrm{x}_{2}$ (kelompok kontrol)

$x_{1}^{2}=$ Deviasi setiap nilai $\mathrm{x}_{1}$ dari rata-rata $\mathrm{x}_{1}$

$\mathrm{x}_{2}^{2}=$ Deviasi setiap nilai $\mathrm{x}_{2}$ dari rata-rata $\mathrm{x}_{2}$

$N=$ Banyaknya subyek/sampel penelitian

Tingkat keefektifan relatif (ER) digunakan untuk menguji seberapa efektif pengaruh pendekatan saintifik terhadap hasil belajar pada siswa kelas III SD Negeri Kebonsari 04 Jember. Menurut Masyhud (2016: 384) rumus untuk menghitung tingkat keefektifan relatif yang sesuai dengan penelitian eksperimen dengan desain Pretest-postest control group design ini adalah sebagai berikut.

$$
E R=\frac{M X_{2}-M X_{1}}{\left(\frac{M X_{1}+M X_{2}}{2}\right)} X 100 \%
$$

Keterangan:

$\mathrm{ER} \quad=$ Tingkat keefektifan relatif perlakuan kelompok eksperimen dibandingkan dengan kelompok kontrol

$M X_{1} \quad=$ Mean atau rerata nilai pada kelompok kontrol

$M X_{2} \quad=$ Mean atau rerata nilai pada kelompok eksperimen

Menurut Masyhud (2016: 385) hasil analisis keefektifan relatif tersebut kemudian ditafsirkan berdasarkan kriteria dalam tabel 2 sebagai berikut.

Tabel 2. Kriteria penafisran uji keefektifan relatif

\begin{tabular}{|c|c|}
\hline $\begin{array}{c}\text { Hasil Uji Keefektifan } \\
\text { Relatif }\end{array}$ & Kategori Keefektifan \\
\hline $0 \leq \mathrm{ER}<20$ & Keefektifan sangat rendah \\
\hline $20 \leq \mathrm{ER}<40$ & Keefektifan rendah \\
\hline $40 \leq \mathrm{ER}<60$ & Keefektifan sedang \\
\hline $60 \leq \mathrm{ER}<80$ & Keefektifan tinggi \\
\hline $80 \leq \mathrm{ER} \leq 100$ & Keefektifan sangat tinggi \\
\hline
\end{tabular}

\section{Hasil dan Pembahasan}

Penelitian ini dilaksanakan di SD Negeri Kebonsari 04 Jember yang berlokasi di Jalan Letjen Sutoyo No 36, Kecamatan Sumbersari, Kabupaten Jember. Pengambilan data dilaksanakan pada tanggal 5 Maret 2018 sampai 28 Maret 2018 di SD Negeri Kebonsari 04 Jember.

Penelitian ini diawali dengan melakukan uji homogenitas terhadap dua kelompok responden yang diteliti yaitu kelas III A dan kelas III B. Uji homogenitas dilakukan untuk mengetahui kondisi awal kedua kelas yaitu kelas III A dan kelas III B sebelum penelitian dilaksanakan. Perhitungan uji homogenitas dilakukan dengan menggunakan SPSS versi 21. Sumber data yang dianalisis dalam perhitungan uji homogenitas yaitu menggunakan nilai pre-test. Adapun hasil uji homogenitas dinyatakan pada tabel 3 berikut.

Tabel 3. Hasil uji homogenitas

\begin{tabular}{|c|c|c|c|}
\hline $\begin{array}{c}\text { Levene } \\
\text { Statistic }\end{array}$ & df1 & df2 & Sig. \\
\hline 0.47 & 7 & 22 & 0.85 \\
\hline
\end{tabular}

Berdasarkan hasil uji homogenitas yang telah dilakukan, diperoleh nilai signifikansi sebesar 0,847 . Nilai tersebut kemudian dikonsultasikan pada taraf signifikansi $5 \%$ atau 0,05. Berdasarkan hasil tersebut dapat dinyatakan bahwa varian dari dua atau lebih kelompok populasi data adalah sama, sehingga dapat diperoleh bahwa keadaan kedua kelas sebelum dilakukan penelitian adalah homogen. Setelah diperoleh keadaan kedua kelas homogen, maka dilakukan pengundian secara acak untuk menentukan kelas eksperimen dan kelas kontrol.

Analisis data yang digunakan untuk menjawab rumusan masalah dalam penelitian ini dilakukan dengan menggunakan uji $\mathrm{t}(t$-test $)$. Perhitungan uji $\mathrm{t}$ dilakukan untuk mengetahui adanya pengaruh yang signifikan hasil belajar siswa pada kelas eksperimen dengan pembelajaran menggunakan pendekatan saintifik dan hasil belajar siswa pada kelas kontrol dengan pembelajaran secara konvensional. Sumber data yang digunakan dalam perhitungan uji $\mathrm{t}(t$-test) adalah selisih nilai pre-test post-test kelas eksperimen dan selisih nilai pre-test post-test kelas kontrol.

Hasil perhitungan uji t (t-test) yang telah dilakukan diperoleh nilai $t_{\text {hitung }}$ sebesar 7,718. Nilai tersebut dikonsultasikan pada $t_{\text {tabel }}$ sebesar 2,042 dengan taraf signifikansi $5 \%$ dengan ketentuan sebagai berikut.

\section{a. Nilai $t_{\text {hitung }} \geq t_{\text {tabel }}$ maka $\mathrm{H}_{0}$ ditolak}

b. Nilai $t_{\text {hitung }}<t_{\text {tabel }}$ maka $\mathrm{H}_{1}$ diterima

Berdasarkan perhitungan hasil pada statistik, diperoleh bahwa nilai $t_{\text {hitung }}>t_{\text {tabel }}$ yaitu $7,718>2,042$. Pada hasil tersebut, terdapat perbedaan yang signifikan antara nilai hasil belajar siswa yang menggunakan pendekatan saintifik dengan nilai hasil belajar siswa tanpa menggunakan saintifik. Dengan demikian dapat diperoleh kesimpulan bahwa ada pengaruh yang signifikan pendekatan saintifik terhadap hasil belajar pokok bahasan persegi, persegi panjang, dan segitiga pada siswa kelas III SDN Kebonsari 04 Jember.

Penelitian ini membahas tentang pengaruh pendekatan saintifik terhadap hasil belajar siswa kelas III. Proses pembelajaran dengan menggunakan pendekatan saintifik adalah mengarahkan siswa agar dapat lebih aktif dalam kegiatan belajar mengajar. Dalam proses pembelajaran ini siswa diajak untuk mengamati objek yang ditunjukkan oleh 
guru dan memberikan kesempatan siswa untuk bertanya terhadap objek tersebut. Kemudian siswa diberikan waktu menalar serta memberikan kesempatan kepada siswa untuk melakukan percobaan bersama teman dalam satu kelompoknya. Setelah siswa melakukan percobaan, siswa mengkomunikasikan hasil percobaanya di depan kelas. Dengan siswa melakukan kegiatan pembelajaran tersebut, diharapkan dapat melatih kemampuan berpikir siswa secara logis dan sistematis. Pendekatan saintifik tepat digunakan pada beberapa materi pembelajaran, karena dalam pendekatan ini pembelajarannya berpusat langsung pada siswa (student centered).

Pada kelas eksperimen (III A) pembelajaran dilakukan dengan menggunakan pendekatan saintifik. Media yang digunakan pada kelas eksperimen adalah kertas lipat (origami). Sebelum dimulai inti pembelajaran siswa diajak pada kegiatan apersepsi yang dilakukan untuk membangkitkan semangat belajar siswa pada materi pembelajaran. Pada kegiatan selanjutnya, siswa diperlihatkan contoh gambar yang mirip dengan sebuah bangun datar dan meminta siswa untuk menyebutkan benda-benda di sekitar atau di dalam kelas yang memiliki bentuk seperti persegi, persegi panjang, dan segitiga.

Langkah pembelajaran berikutnya yaitu guru menghubungkan kegiatan apersepsi dengan materi pembelajaran dengan meminta kepada siswa untuk mengidentifikasi sifat-sifat bangun persegi, persegi panjang, dan segitiga. Selanjutnya, guru membagi siswa menjadi 6 kelompok belajar dengan masing-masing kelompok terdiri dari 5 sampai 6 orang siswa serta membagikan lembar kerja kelompok (LKK) untuk didiskusikan kepada semua anggota pada setiap kelompok dan hasil diskusi dipresentasikan di depan kelas.

Pada kegiatan pembelajaran berikutnya, setiap kelompok menjelaskan hasil diskusi kelompoknya di depan kelas dan kelompok lain menyimak pemaparan dari salah satu temannya yang maju di depan kelas. Kegiatan selanjutnya yaitu guru mengajak siswa untuk menemukan hubungan sisi dan sudut pada bangun persegi, persegi panjang, dan segitiga. Langkah berikutnya dalam kegiatan pembelajaran ini adalah meminta siswa untuk menyimpulkan dan merangkum materi yang telah dipelajari.

Pada kelas kontrol (III B) pembelajaran dilakukan dengan menggunakan pendekatan konvensional. Pendekatan konvensional merupakan pendekatan pembelajaran yang sering digunakan guru dalam proses belajar mengajar di sekolah. Metode dalam pendekatan konvensional yang digunakan adalah ceramah, tanya jawab, dan penugasan. Media yang digunakan pada kelas kontrol adalah gambar bangun persegi, persegi panjang, dan segitiga. Pembelajaran diawali dengan menjelaskan pengertian bangun datar kepada siswa dan mengidentifikasi sifat-sifat bangun persegi, persegi panjang, dan segitiga. Selanjutnya guru memberikan umpan balik yang berupa pertanyaan kepada siswa apakah sudah memahami materi dengan baik atau belum. Kemudian guru memberikan tugas rumah kepada siswa sebagai bahan evaluasi.

Pada pertemuan selanjutnya, guru menjelaskan tentang macam-macam bangun segitiga dan mengidentifikasi dari keempat macam segitiga tersebut. Kemudian guru menanyakan kepada siswa apakah mengalami kesulitan dalam memahami materi pembelajaran atau tidak. Kegiatan berikutnya adalah guru memberikan contoh soal pada bangun datar kepada siswa. Setiap guru selesai menjelaskan materi pembelajaran, guru selalu bertanya kepada siswa apakah siswa sudah dapat memahami materi dengan baik atau belum dan siswa menjawab tidak mengalami kesulitan dalam memahami materi. Akan tetapi, masih banyak siswa yang belum dapat mengerjakan dengan baik tugas rumah yang sebelumnya diberikan oleh guru.

Siswa pada kelas eksperimen (III A) dibelajarkan untuk mengidentifikasi bangun datar sederhana yaitu persegi, persegi panjang, dan segitiga dengan membentuk diskusi pada masing-masing kelompok. Pembelajaran pada kelas eksperimen didukung dengan media pembelajaran yang nyata sehingga dapat digunakan siswa untuk mempermudah mengidentifikasi bangun persegi, persegi panjang, dan segitiga. Selain itu proses diskusi kelompok secara tidak langsung juga dapat membantu siswa mengingat serta memahami materi dengan baik karena siswa terlibat melakukan kegiatan. Pembelajaran dengan menggunakan pendekatan saintifik mengutamakan pada proses yang dialami siswa pada saat kegiatan belajar mengajar berlangsung. Siswa pada kelas eksperimen juga dapat lebih bersemangat dalam mengikuti proses pembelajaran karena siswa menemukan sendiri konsep-konsep tentang bangun datar sederhana dan tidak hanya mendengarkan penjelasan dari guru.

Melalui pendekatan saintifik, pembelajaran matematika yang berhubungan/dengan materi bangun datar diberikan dengan menggunakan media nyata dapat memberikan kesan pembelajaran yang menarik dan tidak membosankan. Pembelajaran matematika dengan menggunakan media yang nyata dapat mempengaruhi keterampilan siswa dalam menyusun konsep pengetahuan yang dipelajari karena mata pelajaran matematika lebih menekankan materi pembelajaran yang bersifat abstrak. Materi pembelajaran matematika yang bersifat abstrak dengan dibantu media yang nyata dapat memudahkan siswa memahami materi yang diajarkan karena media yang digunakan bersifat konkrit dan sesuai dengan tingkat kemampuan berpikir siswa.

Berdasarkan pembahasan tersebut, dapat disimpulkan bahwa ada pengaruh yang signifikan pendekatan saintifik terhadap hasil belajar pokok bahasan bangun persegi, persegi panjang, dan segitiga pada siswa kelas III SD Negeri Kebonsari 04 Jember. Hal ini sesuai dengan penelitian relevan sebelumnya yang mengatakan bahwa dengan menerapkan pembelajaran dengan pendekatan saintifik pada siswa berpengaruh secara signifikan terhadap hasil belajar, sehingga hasil belajar siswa dapat menjadi lebih baik dari pada sebelumnya.

\section{Kesimpulan dan Saran}

Berdasarkan hasil analisis data dan pembahasan yang telah dijelaskan, dapat disimpulkan bahwa ada pengaruh yang signifikan pendekatan saintifik terhadap hasil belajar pokok bahasan bangun persegi, persegi panjang, dan segitiga pada siswa kelas III SDN Kebonsari 04 Jember Tahun Ajaran 2017/2018. Hal tersebut dapat dilihat pada perhitungan uji 
hipotesis dengan menggunakan uji t (t-test) pada kedua kelas, yaitu kelas eksperimen dan kelas kontrol. Berdasarkan hasil perhitungan uji $\mathrm{t}(\mathrm{t}$-test) yang telah dilakukan diperoleh hasil bahwa $t_{\text {hitung }}$ sebesar 7,718 dan $t_{\text {tabel }}$ sebesar 2,042 pada taraf signifikansi 5\%. Berdasarkan ketentuan tersebut, maka $t_{\text {hitung }}>t_{\text {tabel }}$ atau dapat ditulis 7,718 $>2,042$ sehingga hipotesis nihil $\left(\mathrm{H}_{0}\right)$ ditolak dan hipotesis alternatif $\left(\mathrm{H}_{1}\right)$ diterima. Selain dengan uji t, dilakukan perhitungan menggunakan uji keefektifan relatif (ER). Hasil perhitungan diperoleh nilai keefektifan relatif (ER) sebesar 71,88\% yang termasuk dalam kategori keefektifan tinggi. Berdasarkan perhitungan uji t ( $t$-test) dan keefektifan relatif (ER) yang telah dilakukan dapat disimpulkan bahwa ada pengaruh yang signifikan pendekatan saintifik terhadap hasil belajar pokok bahasan persegi, persegi panjang, dan segitiga pada siswa kelas III SDN Kebonsari 04 Jember.

Berdasarkan pembahasan dan kesimpulan yang telah diperoleh, maka terdapat beberapa saran sebagai berikut.

a. Bagi kepala sekolah, proses pembelajaran dengan menggunakan pendekatan saintifik dapat menciptakan pembelajaran yang aktif dan memberikan dampak yang positif terhadap hasil belajar siswa. Diharapkan para guru dapat menggunakan pendekatan saintifik pada materi pembelajaran matematika, khususnya bangun datar atau geometri.

b. Bagi guru, penggunaan pendekatan saintifik dalam proses pembelajaran memerlukan kesiapan siswa dalam kegiatan belajar mengajar. Untuk itu, guru dapat memperbaiki konsep dan pemahaman khususnya dalam matematika agar hasil belajar siswa dapat menjadi lebih baik.

c. Bagi peneliti lain, penelitian dengan pendekatan saintifik ini lebih menekankan kepada ranah kognitif untuk mengetahui hasil belajar siswa. Hasil penelitian ini dapat dijadikan sebagai bahan pertimbangan pada penelitian selanjutnya yaitu dengan menambahkan media pembelajaran sebagai bahan untuk diuji cobakan pengaruhnya terhadap hasil belajar siswa.

\section{Daftar Pustaka}

[1] Hobri. 2010. Metodologi Penelitian Pengembangan (Aplikasi pada Penelitian Matematika). Jember: Pena Salsabila.

[2] Kementerian Pendidikan dan Kebudayaan. 2013. Diklat Guru dalam Rangka Implementasi Kurikulum 2013. Jakarta: Direktorat Jenderal Pendidikan Tinggi.

[3] Masyhud, S. 2016. Metode Penelitian Pendidikan. Edisi ke 5. Jember: Lembaga Pengembangan Manajemen dan Profesi Kependidikan (LPMPK).

[4] Musfiqon, H.M., Nurdiansyah. 2015. Pendekatan Pembelajaran Saintifik. Edisi Pertama. Sidoarjo: Nizamia Learning Center.

[5] Sugiarti, T., Sunardi, dan A.M. Desbi. 2016. Analisis Kemampuan Berpikir Kreatif Siswa dalam Memecahkan Masalah Divergen Sub Pokok Bahasan dan Segiempat Berdasarkan Kemampuan Matematika. Kadikma. 7(1). 10-21.

[6] Sunardi, A.F. Ramadhani, dan E. Oktavianingtyas. 2017. Analisis Tingkat Berpikir Kreatif Siswa Gaya Belajar Visual dalam Memecahkan Masalah Persegi Panjang dan Persegi. Kadikma. 8(1): 31-39.

[7] Susanto, A. 2013. Teori Belajar dan Pembelajaran SD. Jakarta: Kencana Drenada Media Group. 